\title{
Spatial modeling approach to clustering the furniture industry and regional development in Jepara, Indonesia
}

\author{
By Rubeta Andriani ${ }^{1)}$, Ramadhani Achdiawan ${ }^{1)}$, Herry Purnomo ${ }^{1,2)}$, Atie Puntodewo ${ }^{1)}$, and Rika Harini \\ Irawati $^{1)}$ (email: randriani@,cgiar.org) \\ 1) Center for International Forestry Research (CIFOR), Bogor Barat 16115, Indonesia \\ 2) Faculty of Forestry, Bogor Agricultural University
}

\begin{abstract}
In Indonesia, about $95 \%$ of the furniture industry is managed by small and medium scale enterprises (SMEs). These SMEs have formed natural clusters, which are not efficiently distributed in terms of obtaining raw materials and marketing. This inefficiency reduces the competitive edge of the Indonesian SMEs, which then lose out to the Chinese and Vietnamese furniture industries. This paper provides a spatial analysis of the SME-based furniture industry in Jepara, Central Java, which contributes $10 \%$ to the national export value (US\$ 1.5 billion). The spatial analysis comprises elements of workshops, tree plantations, log yards, warehouses, showrooms, sawmills, ironmongeries and local markets. This study aims to analyze the spatial context of efficiency in the Jepara furniture industry that may provide options for more efficient SME clustering in connection with regional development, including recommending a future location for the furniture industry. The analysis indicates that the efficiency of the furniture industry in Jepara, reflected in its gross revenue, is determined by its proximity to the retailers rather than wood suppliers. The higher the $\mathrm{R}^{2}$ of the correlation of distance to furniture retailers indicates that furniture is more buyer driven than raw material driven. Future development of Jepara needs to consider the spatial configuration of furniture retailers, wood suppliers as well as the road network to improve the annual gross revenue, as one of indicators of efficiency.
\end{abstract}

Keywords: spatial modeling, Small Scale Medium Enterprises, furniture, efficiency, regional development 
Andriani et al., Spatial modeling approach to clustering the furniture industry and regional development in Jepara, Indonesia

\section{INTRODUCTION}

Around $95 \%$ of the Indonesian furniture industry, particularly in Java, is managed by small-scale and medium enterprises (SMEs). Jepara, situated on the north coast of Central Java, has long been a significant furniture industry player in Indonesia. In 2005 the industry provided livelihoods for around five million people directly and indirectly in 15,271 associated enterprises (Roda, et al 2007). By 2010 the total number of enterprises dropped to 11,981, some 11,597 of which were independent enterprises and the rest integrated enterprises. Independent enterprises, such as workshops or sawmills, focus on specific activities, while integrated enterprises are business units that integrate two or more activities, a workshop and showroom, or a $\log$ yard and sawmill. Out of the total number of enterprises, $92 \%$ were categorized as small scale producers (Achdiawan and Puntodewo, 2011). These industries contributed 27\% to the Jepara District's income in 2009 , and accounted for $10 \%$ of the national export value (US\$ 1.5 billion).

The industry increased significantly during the export boom era of 1997/98. The SMEs in Jepara formed natural clusters, which are now not efficiently distributed in terms of obtaining raw materials and marketing. Prestvik (2008) tried to find the efficiency and constraints of small-scale furniture producers in the district of Jepara by looking at its economic perspectives. The research indicated that due to low investment costs required to start a new furniture venture, large numbers of small furniture workshops were established during the boom. However, failing to maintain their competitiveness, many exited soon after the boom. Inefficiency, mostly related to their inability to cope with the increasing price of raw materials and fulfilling market demands, were seen as the main causes of the exits.

This paper aims to analyze the spatial context of efficiency in the Jepara furniture industry to complement the previous studies conducted within this project. Efficiency in the spatial context is based on the industrial location theory that indicates efficiency as the total reduction in production costs, including minimizing transportation costs (Nugroho, 2010). Based on this theory, it is assumed that efficiency in the spatial context can be achieved when furniture industry actors in Jepara can reduce the above mentioned costs. The efficiency then can be viewed from two perspectives, upstream, looking at the distance from the suppliers, and downstream, the distance from the market side. These perspectives are viewed to provide comprehensive pictures of small and medium producers in order to identify and increase efficiency.

\section{METHODS}

The two sets of data, obtained from a previous stage of the project, were used to conduct the spatial analysis of efficiency of the furniture industry in Jepara. The first set of data, from a spatial census, recorded 11,981 furniture enterprises in Jepara. The second set of data was a detailed intensive survey of $17 \%$ or 2000 of the furniture enterprises. The aim of the survey was to obtain further details of the characteristics of the furniture industry. Data from the survey were then used to analyze the current efficiency of the Jepara furniture industry, and to model the future efficiency of the industry.

Efficiency occurs in 2 nodes within the value chain, namely upstream and downstream efficiency. The upstream efficiency is described in terms of the physical distance from producers (workshops and warehouses) to suppliers - both wood suppliers and non-wood suppliers. The wood suppliers include log yards, sawmills, kiln and drying yards, and non-wood suppliers are the ironmongeries. Downstream efficiency is defined as the physical distance from producers (workshops and warehouses) to retailers (showrooms). Hypothetically, the efficiency of the furniture industry in Jepara will affect the industry's revenue, which in this study is gross revenue. The more efficient the industry, the larger the expected gross revenue. Since efficiency is defined by the reduced operation costs and time, i.e. transportation costs to suppliers and retailers, therefore, the less transportation costs, the more efficient the industry.

\section{RESULTS}

\subsection{Spatial distribution of the furniture industry}

The survey in 2010 indicated that the number of furniture enterprises had fallen by $20 \%(15,271$ to 11,981$)$ in the five-year period from 2005 to 2010 (Achdiawan and Puntodewo, 2011). The furniture industry are mainly located in the sub districts of Pakisaji, Batealit, Tahunan, Jepara, Mlonggo and Bangsri (Figure 1). Based on the total number of workers, $98 \%$ of furniture workshops in Jepara are classified as small-scale 
Andriani et al., Spatial modeling approach to clustering the furniture industry and regional development in Jepara, Indonesia

businesses ( $<20$ workers), $1.9 \%$ are medium-scale (20-100 workers) and $0.1 \%$ are large-scale $(>100$ workers).

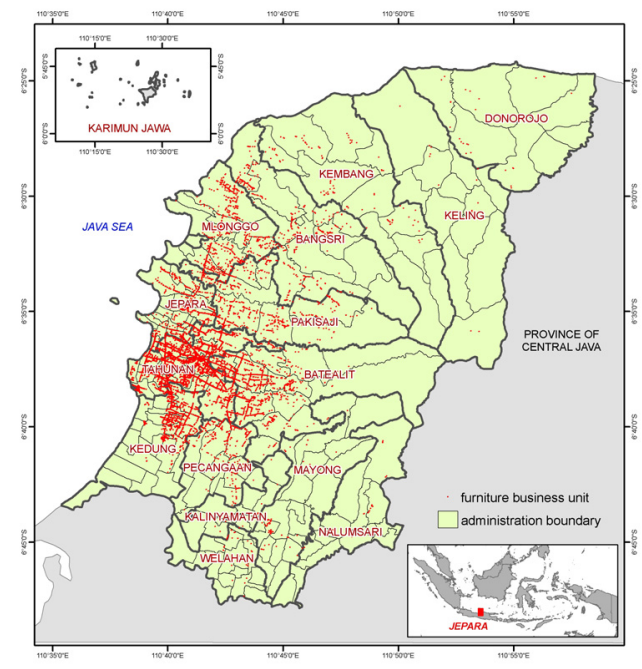

Figure 1. The distribution of furniture enterprises in Jepara (inset Indonesia)

Figure 2 describes the distribution of furniture industries: (a) workshops, (b) wood suppliers, and (c) retailers for each village in Jepara. The darker colors indicate higher occurrences of the industry in question. The color scheme is calculated by the number of each industry present in each village divided by the total number of similar industry in Jepara.

Tahunan, Batealit, and Kedung sub-districts have the highest density of furniture workshops and accounted for almost $70 \%$ of workshops, in Jepara. The wood suppliers in Tahunan, Jepara and Batealit sub-districts account for more than $70 \%$ of the total wood suppliers in Jepara. However, local wood suppliers are only able to fulfill around $24 \%$ of the total industry's wood demand in Jepara, while the rest is filled by suppliers outside Jepara. Retailers in Jepara are mostly distributed in Tahunan, Jepara and Batealit sub-districts, which together account for almost $95 \%$ of retailers in Jepara. This figure indicates that Tahunan sub-district has the highest density of furniture enterprises in Jepara, consisting of $43 \%$ of workshops, $44 \%$ of wood suppliers, and $77 \%$ of retailers in Jepara.

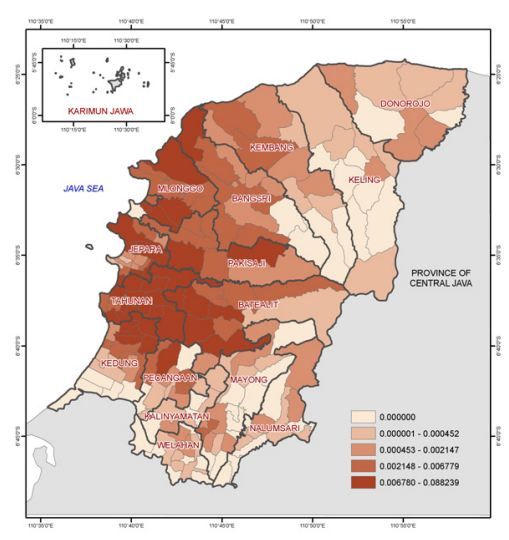

(a) Workshops

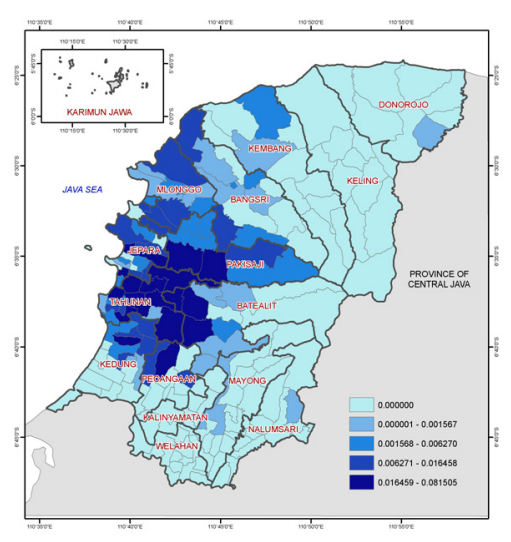

(b) Wood suppliers

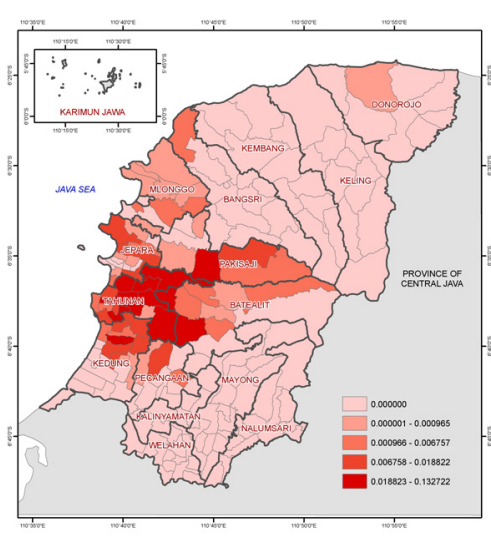

(c) Retailers

Figure 2. Distribution of the furniture industries in Jepara 
Andriani et al., Spatial modeling approach to clustering the furniture industry and regional development in Jepara, Indonesia

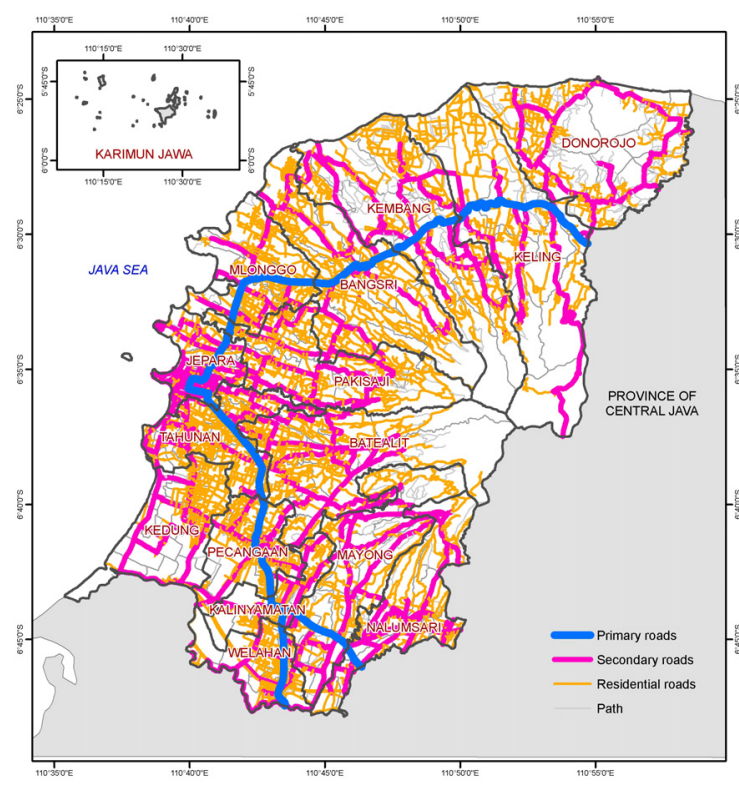

(a) Road networks

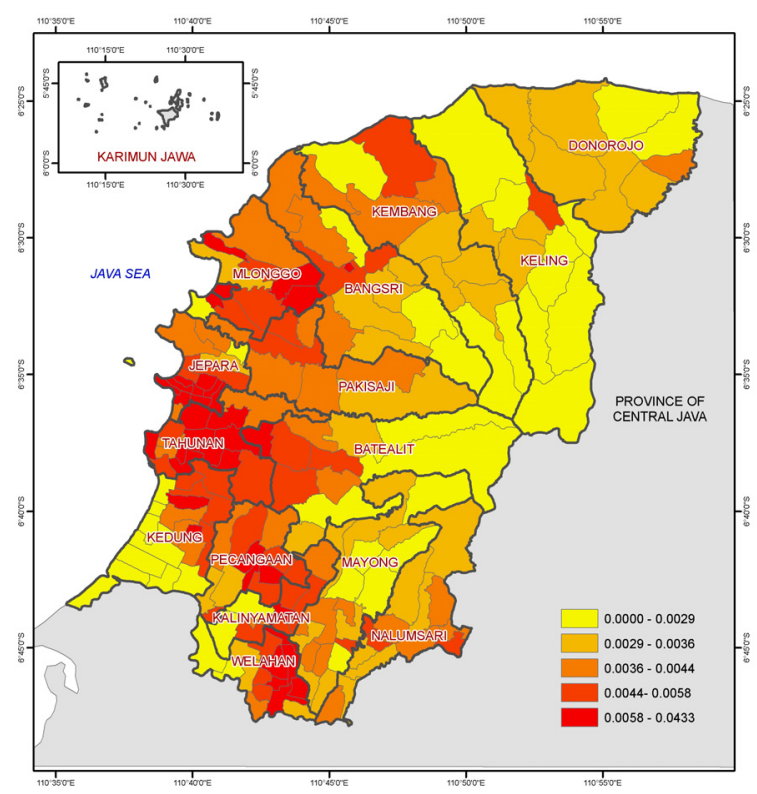

(b) Road density

Figure 3. The spatial distribution of roads in Jepara

Figure 3 shows the road networks (a) and its density (b) in Jepara. The main road that passes through Jepara is the district road that connects Jepara to Pati district. This road has played an important role in the development of the furniture industry in Jepara. It connects all furniture industry players, such as producers with their supplier as well as with the retailers for local markets. This road is also important as it facilitates the transportation, of products for export, to the main harbor in Semarang, the capital city of Central Java.

The road density was calculated based on the sum of the total length of all types of roads that is presence in each village divided by the total area of the village. Tahunan sub-district has the highest road density followed by Welahan and Kalinyamatan sub-districts.

\subsection{Spatial Analysis}

Table 2 shows the median value of the furniture industry's producers (workshops and warehouses) in Jepara related to the distance to wood suppliers and to markets represented by furniture retailers, the road density as well as the annual gross revenue. The table shows that Tahunan sub-district is the closest to the three components, with a road density of $0.0066 \mathrm{~m} / \mathrm{m} 2$. It also shows that Tahunan, has the highest annual gross revenue compared to the other sub-districts, followed by Jepara and Batealit sub-districts. Tahunan furniture enterprises have benefited from being in closer proximity to both the suppliers and the market. Tahunan subdistrict is known to have the longest line of furniture showrooms, located on the main road, connecting Jepara and Pati, Central Java. The table also shows that the annual gross revenue of areas such as Keling and Donorojo which are further from wood suppliers as well as retailers tends to be lower. 
Andriani et al., Spatial modeling approach to clustering the furniture industry and regional development in Jepara, Indonesia

Table 1. Gross revenue and distance to wood suppliers and furniture retailers for each sub-district

\begin{tabular}{|c|c|c|c|c|}
\hline Sub-district & $\begin{array}{l}\text { Distance } \\
\text { to Wood } \\
\text { Supplier } \\
(\mathrm{km})\end{array}$ & $\begin{array}{l}\text { Distance to } \\
\text { Furniture } \\
\text { retailers } \\
(\mathrm{km}) \\
\end{array}$ & $\begin{array}{c}\text { Road } \\
\text { density }\end{array}$ & $\begin{array}{l}\text { Annual gross } \\
\text { revenue (in } \\
\text { million Rp.) }\end{array}$ \\
\hline Bangsri & 1.46 & 10.48 & 0.0038 & 231,152 \\
\hline Batealit & 0.78 & 0.79 & 0.0052 & $1,308,344$ \\
\hline Donorojo & 15.64 & 25.22 & 0.0033 & 6,788 \\
\hline Jepara & 0.75 & 1.04 & 0.0043 & $1,312,824$ \\
\hline Kalinyamatan & 1.88 & 3.14 & 0.0058 & 23,528 \\
\hline Kedung & 0.46 & 0.62 & 0.0055 & 402,600 \\
\hline Keling & 10.58 & 21.24 & 0.0029 & 3,372 \\
\hline Kembang & 3.16 & 14.68 & 0.0039 & 24,924 \\
\hline Mayong & 1.78 & 4.16 & 0.0037 & 27,978 \\
\hline Mlonggo & 0.90 & 7.22 & 0.0052 & 572,754 \\
\hline Nalumsari & 8.11 & 10.92 & 0.0039 & 8,374 \\
\hline Pakisaji & 1.02 & 3.24 & 0.0043 & 321,344 \\
\hline Pecangaan & 0.76 & 1.22 & 0.0057 & 467,858 \\
\hline Tahunan & 0.29 & 0.17 & 0.0066 & $3,306,500$ \\
\hline Welahan & 4.16 & 6.19 & 0.0059 & 7,380 \\
\hline
\end{tabular}

The gross revenue is found to have significant positive correlation with road density and negative with distance to wood suppliers and furniture retailers. The pattern of gross revenue as shown in Figure 4 indicates the pattern differences of gross revenue from the patterns of distance to wood suppliers and furniture retailers.

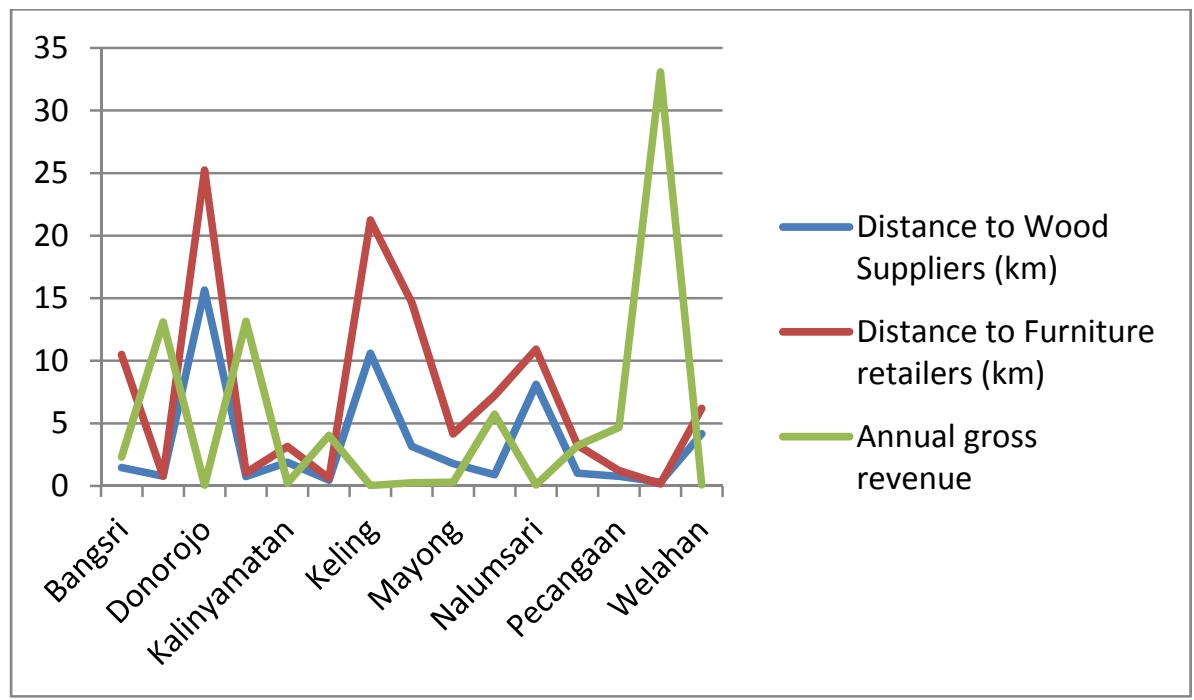

Figure 4. Gross revenue $\left(\operatorname{Rp} 10^{10}\right)$ has a negative correlation with distance to wood suppliers $(\mathrm{km})$ and furniture retailers $(\mathrm{km})$

Logarithmic regression was applied to model the relationship between gross revenue as a function of efficiency. Where efficiency is defined as distance to both furniture retailers and wood suppliers. The model follows the basic logarithmic equation of $y=a e^{b x}$.

Variable ' $y$ ' is gross revenue, ' $a$ ' is constant and ' $b$ ' is coefficient of ' $x$ ', which is distance to furniture retailers or wood suppliers. The downstream efficiency model and gross revenue are described in Figure 5 and upstream efficiency and gross revenue are described in Figure 6 . The coefficient determination $\left(\mathrm{R}^{2}\right)$ of 
Andriani et al., Spatial modeling approach to clustering the furniture industry and regional development in Jepara, Indonesia

the downstream model is $61.8 \%$ with a P-value of 0.001 . While the coefficient determination $\left(\mathrm{R}^{2}\right)$ of the upstream regression model is $43.0 \%$ with a P-value of 0.007 . Both correlations are significant.

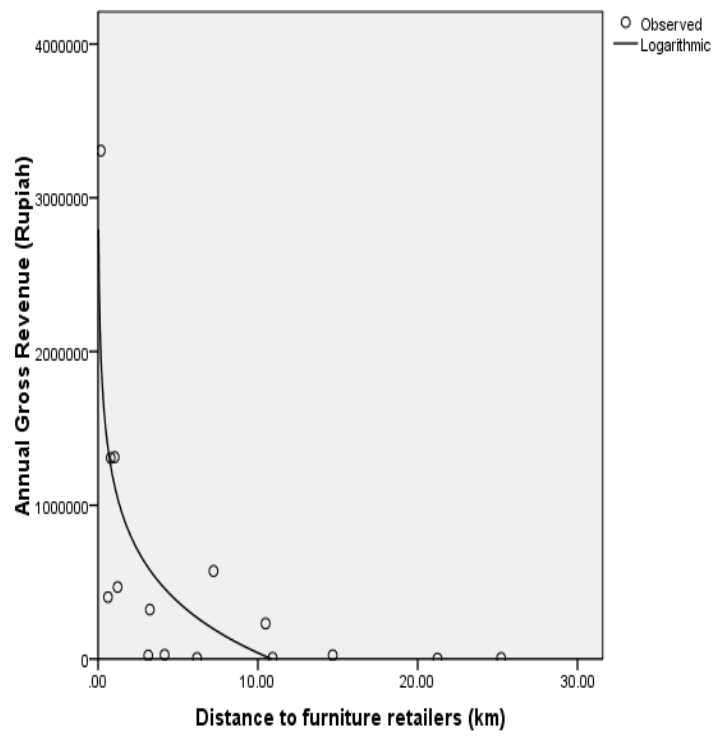

Figure 5. Logarithmic model of gross revenue of furniture workshops as a function of distance to furniture retailers

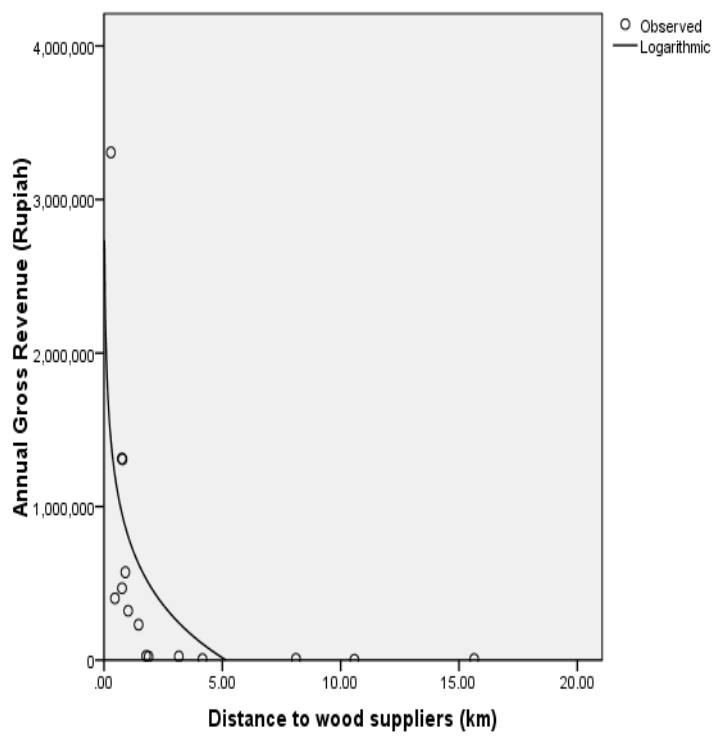

Figure 6. Logarithmic model of gross revenue as a function of distance to wood suppliers

\section{DISCUSSION}

The distance to retailers from the furniture workshops was found to be more important than the distance to wood suppliers in terms of gross revenue. This suggests that the furniture industry is more buyer driven than raw material driven. To improve the revenue, the workshops need to be close to the retailers and thus buyers. While the distance to retailers maybe more important, this does not lessen the significant correlation between gross revenue and the distance to wood suppliers. Downstream efficiency is found to be more important than upstream efficiency. This can be understood from the fact that the highest value added for 
Andriani et al., Spatial modeling approach to clustering the furniture industry and regional development in Jepara, Indonesia

furniture lies in marketing and design, which in turn will increase the gross revenue. With regard to the international markets, the Jepara furniture industry can maintain its competitive edge if it maintains high quality, and good design. Together with good marketing, the industry can survive.

The furniture workshops receive greater benefits from the existing roads. A good road network provide buyers with easy access to furniture workshops. They can order or buy furniture directly from the workshops. In most cases the workshops do not sell finished furniture but unfinished products. Some buyers prefer to buy unfinished products due to their low price. The majority of these unfinished products will be processed further and then sold as finished furniture.

Clustering furniture workshops, with a good road network, is a must and should be located close to furniture retailers to obtain greater downstream efficiency. In terms of Jepara, the workshops located close to Tahunan Sub-District, the centre of furniture retailers, are the most efficient. The main problem with this concept is the availability of suitable land for furniture workshops close to the retailers. This situation needs to be resolved through integrated development of Jepara. While workshops located in Tahunan, Jepara and Batealit Sub-districts have had the highest gross revenue, Kedung and Pecangaan Sub-districts, with their good road network and close proximity to furniture retailers and wood suppliers, have excellent potential for further development .

Jepara development needs considerable investment to increase downstream and upstream efficiencies of the workshops. New investment would need to consider factors such as road networks, location of furniture retailers and wood suppliers. The government might also invest in market development to boost the income of furniture workshops in less developed areas. Further research to understand the driving factors behind low gross revenue in areas that have good access to roads and markets is recommended.

\section{CONCLUSION}

Furniture workshops in Jepara have different downstream and upstream efficiencies. There is significant correlation between the location of furniture workshops and the distance to the furniture retailers and wood suppliers. Higher $\mathrm{R}^{2}$ of the correlation of distance to furniture retailers indicates that furniture is more buyer driven than raw material driven. Future development of Jepara needs to consider spatial configuration of furniture retailers, wood suppliers as well as the road network to improve downstream and upstream efficiencies, which in turn improve the annual gross revenue.

\section{REFERENCES}

Achdiawan R, and Puntodewo A. 2011. Livelihood of Furniture Producers in Jepara. Furniture Value Chain Project Annual Report 2011. CIFOR. Bogor

Nugroho, P., 2010, Reconciling Industrial Clusters and Urban Systems through Regional Network Governance: A Case of Central Java Province Journal of Indonesian Economy and Business, v. 25, number 1, 2010, p. 59-76.

Prestvik AS. 2008. Survey report of Small-scale furniture producers in Jepara. Department of Economics and Resource Management, Norwegian University of Life Sciences

Roda, J.-M., Cadene, P., Guizol, P., Santoso, L. \& Fauzan, A. U. 2007. Atlas of wooden furniture industry in Jepara, Indonesia. Bogor, Indonesia, French Agricultural Research Centre for International Development (CIRAD) and Center for International Forestry Research (CIFOR). 